\title{
The role of sustainable transport system in the competitiveness of agri-food products
}

\author{
Mariam Saghareishvili ${ }^{*}$ \\ ${ }^{1}$ Ivane Javakhishvili Tbilisi State University, 1 Ilia Chavchavadze Avenue, Tbilisi, Georgia
}

\begin{abstract}
The article discusses the role of sustainable transport systems in competitiveness of Georgian agri-food products. Georgian agri-food products are less competitive on international markets. The country has FTAs with its partners that should make Georgian goods more competitive, at least in terms of price. Transport and logistics is one of the main parts of export, therefore, they have an impact on competitiveness of exported goods. Georgia trades with its neighbour countries, with the EU, China, etc. The EU and China represent huge markets and Georgian government targets to increase export in both directions, but there is a long distance between Georgia and its target markets, therefore it needs a developed transport and logistics system. On the other hand, portions of exported Georgian agri-food products are primary production, which have a shorter lifetime period, that's why they should be transported in a short period of time, with specific machines. Without development of the transport system it is impossible to achieve sustainable export of agri-food products into Georgia's target markets. Investments in the system, with tangible strategy and holistic approach can create a sustainable transport system that will increase competitiveness of Georgian agri-food products in international markets.
\end{abstract}

\section{Introduction}

Agricultural sector in Georgia faces many challenges, one of which is agri-food competitiveness on international markets. Georgian government implements programs and projects to support the sector. Trade liberalization is one of the ways of increasing competitiveness of a country's goods and services.

In order to liberalize trade, countries apply for free trade agreements. Georgia also pursues a policy of trade liberalization, the country shares the principles of the World Trade Organization and at the same time, has already signed free trade agreements with many countries. Georgian companies trade with EU countries, the European Free Trade Association (EFTA) countries, China, Hong Kong, Turkey, the Russian Federation, Azerbaijan, Armenia, Ukraine, Moldova, Kazakhstan, Uzbekistan and Turkey within the framework of the free trade regime.

The free trade agreement with these countries includes the simplified circulation of both products and, in some cases, services between the countries.

\footnotetext{
${ }^{*}$ Corresponding author: m.saghareishvili@iset.ge
} 
The terms of the agreement, of course, apply to agricultural products. Free trade ensures the free movement of goods and services between countries. In addition, free trade ensures that countries share knowledge, experience and modern approaches and technologies. By sharing modern approaches and technological knowledge it is possible to increase productivity, production and competitiveness on different markets.

Competitiveness of agri-food products depends on several factors. For example, costs of production, quality of the products which can be achieved by following international standards of food production, developed logistics and supply chain of the products.

Development of competitiveness of agricultural products is impossible without a sustainable supply chain and transport system has an important role in it. Sustainable transport systems can positively contribute to competitiveness of agri-food products on international markets. Sustainable transport systems are able to provide efficient mobility of goods and services across and outside the country.

Improvement of transport systems can be achieved by increased investments in the sector. Investments lead to increased transport capacity, higher efficiency and quality service. Benefits of developed transport systems are low transport costs, short transit time, ability to expand a business, increased productivity, all of which results in increased competitiveness and economic growth [1].

This article assesses the impact of sustainable transport systems on competitiveness of agri-food products on international markets. The article reviews the role of the transport system in competitiveness in different countries. Also, it discusses how Georgian transport system is developed and how it contributes to competitiveness of agri-food products.

\section{Literature review}

Competitiveness itself is defined by different economists and institutions. Most common definition of competitiveness is by Michael Porter, who defines competitiveness as national productivity, providing a higher standard of living and employment [2].

Sustainable transport system is a capacity that ensures mobility of the society with the least damageable manner to the environment and does not decrease mobily of the future generation [3].

Many countries recognize the role of a sustainable transport system in an economy and competitiveness. For example, researchers in Lithuania analyzed the effect of a sustainable transport system on the competitiveness of the national economy. Lithuania's economy benefited from transportation through improved mobility and improved quality of service. However, development of transport systems has its drawbacks which mainly is associated with increased noise and air pollution, and increased number of traffic accidents. Considering the drawbacks, overall, allocation of investment in the transport system gave Lithuania a chance to increase economic competitiveness and achieve rapid economic growth [1].

Investments in transport infrastructure improve accessibility of the regions however, its impact on competitiveness is unclear [4]. Transport system consists of three markets: trip, transport and traffic markets. Trip market consists of distribution of location and time. In the transport market, vehicles represent the supply side and trip patterns represent the demand side. In the traffic market, the supply side consists of infrastructure and traffic control systems. All three markets must work properly to have a sustained transport system and improve accessibility. Other factors that affect accessibility are mobility, integrated transport system, affordability of transport, transport network connectivity, management of roadways.

The article "Transport and agricultural productivity: a cross-national analysis" discusses the role of transport infrastructure in agricultural development. 
To measure the link between the two, authors use data for transport infrastructure meaning total road network (highways, main and secondary roads, etc.); agricultural production; agricultural inputs, such as land and machinery; and education. Empirical analyses showed that comparing two countries with the same education level and agricultural inputs, a country with a better transport system can produce more agricultural goods. This is a direct effect of a sustainable transport system on agricultural productivity, while there also is an indirect effect which implies that accumulation of a sustainable transport system means accumulation of infrastructure in the country, that can increase countries productivity and cause higher economic growth [5].

Sustainable transports and logistics not only increase competitiveness of agricultural products but also increase food security, which became even more important during the Pandemic. Avoiding food waste and efficient allocation of products is vital in periods of lockdowns and limited transportation [6].

\section{Methodology}

To identify the role of sustainable transport system in competitiveness of Georgian agrifood products, the article discusses the following pillars:

- Types of transport in Georgia, especially for export purposes;

- Currents state of transport system in Georgia;

- Competitiveness of agri-food products in Georgia;

- Factors that hinder development of transport system in Georgia;

- The role of sustainable transport systems in competitiveness of agri-food products.

To outline agri-food export tendency and most common means of transport in Georgia's export, the data of the national statistics office of Georgia was reviewed. To evaluate Georgia's current situations in terms of transport system, the paper also discusses Georgia's positions in international rankings related to transports and logistics.

\section{Analysis}

Agricultural sector has been prioritized by Georgian government since 2012 and a lot of programs and projects have been implemented to increase productivity and competitiveness of the sector [7]. One of the aims of the Ministry of Environmental Protection and Agriculture of Georgia is to increase competitiveness of Georgian agri-food products. Moreover, the government aims to develop agricultural value chains, part of which is transport and logistics [7]. Georgian agriculture is characterized by production of primary goods rather than secondary goods. This means that low value added products are produced in a country, rather than high value added products. Primary products have low prices, but the prices still are not competitive on international markets.

According to the National Statistics Office of Georgia, total export of food products amounted to 317 million USD in 2020. On average the share of agri-food export in total export was $9.3 \%$ in 2020, which is higher than the same variables in 2018 and 2019. Table 1 shows the top ten agri-food products exported from Georgia, where fruits, vegetables, wheat represent primary products.

Development of supply chains and value chains have vital importance for increasing competitiveness of agro-food products [8]. One of the main parts of the supply chain are transport and logistics. This part of the chain is important not only for international markets but for mobility of the goods and services within a country. 
Table 1. Top ten food products exported from Georgia [16].

\begin{tabular}{|c|c|}
\hline Products & Value (million USD) \\
\hline Wine & 210.3 \\
\hline Fruit & 144.5 \\
\hline Spirits & 132.2 \\
\hline Mineral waters & 116.6 \\
\hline Soft drinks & 31.6 \\
\hline Vegetables & 10.3 \\
\hline Beer & 5.1 \\
\hline Sugar & 2.2 \\
\hline Vegetable oil & 0.5 \\
\hline Wheat & 0.01 \\
\hline
\end{tabular}

Georgia's transport system consists of road, railways, sea and air transport and pipelines [9]. Transport infrastructure is improving every year, the government implements investment projects to modernize the infrastructure. Main sources of transport for food products are sea and road transport. According to the National Statistics office of Georgia, in $2020 \$ 3.3$ billion was exported from Georgia, of which $47 \%$ was exported by sea and $42 \%$ by road transport, only $11 \%$ of total export was through air transport and railway (Fig. $1)$.

\section{Export by means of transport}

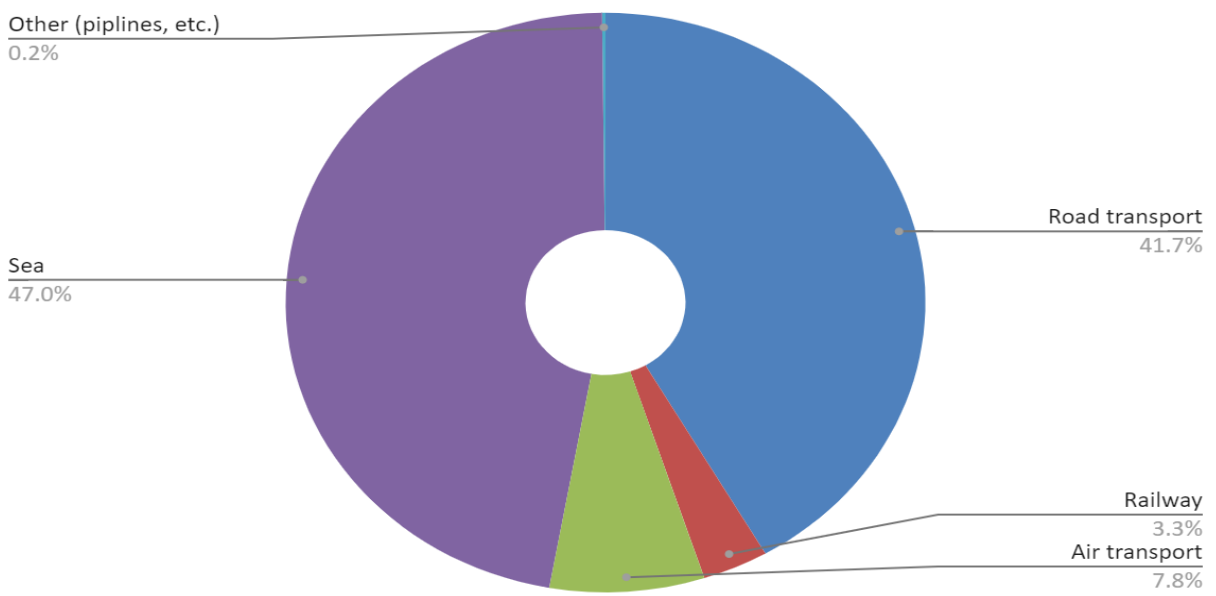

Fig 1. Export by means of transport [12]. 
Usage of sea transport has been increasing every year since 2016 . It increased by $5 \%$ in 2020. Usage of road transport was also increasing from 2016 until 2020, however it sharply declined by $26 \%$ in 2020 compared to the previous year.

Usage of air transport and railways were also increasing from 2016 until 2020, however they declined in 2020 by $0.3 \%$ and $25 \%$, respectively. Decrease of road, air and railway transport can be explained by COVID-19 outbreak in the world, which caused lockdowns in most of the countries in the world and created delays in supply chains. Representatives of the agricultural sector struggled with pandemic restrictions, according to the survey "COVID-19 impact on Georgian farmers and agriculture" $55 \%$ of surveyed farmers face challenges in transportation due to COVID-19 restrictions [10].

In the World Bank Logistics Performance Index Georgia ranked 119 in 2018. The index evaluates supply chain service delivery, which includes six indicators - customs, infrastructure, international shipments, service quality, tracking and tracing, timeliness. Among the indicators, Georgia has the highest rank in customs, the rest indicators have the following ranking [11]: Customs (95); Infrastructure (102); Timeliness (105); International shipments (124); logistics quality and competence (132); tracking and tracing (139).

Overall, Georgia's logistics performance is quite low with underdeveloped infrastructure, delays in delivery and quality of logistics service. Competitiveness of Georgian goods and services will improve if its logistics will become more predictable and reliable, especially, shipment delivery.

Georgia ranked 74 in the Global Competitiveness Index by the World Economic Forum in 2019 [12]. The index consists of 11 pillars, one of which is infrastructure. The pillar consists of transport and utility infrastructure. Transports infrastructure ranks 83 and it evaluates the country's performance in road connectivity, quality of read infrastructure, railroad density, efficiency of train services, airport connectivity, efficiency of air transport services, liner shipping connectivity, efficiency of seaport services. Within the pillar efficiency of train services has the highest rank (43), while liner shipping connectivity - the worst (100). Georgia's performance in the international rankings show that transport infrastructure has to be developed further in the country.

Georgia targets to increase its export to European Union. Having a Free Trade Agreement with the EU is a good basis for it. However, Georgian agri-food products are not competitive on the EU market. The value chain analyses of several agricultural products with high export potential in European Union admit that transportation has one of the main roles in competitiveness of agricultural products. As a lot of goods in Georgian agri-food exports represent primary goods, their transportation requires special containers and freezing machines.

Hiring this type of machine is costly. Insurance of the cargo is an important part of the export, however, it increases the costs as well. According to the study, transportation of goods in Europe costs about 4000-5000 euro. This cost is quite high for primary food producers, that is why they prefer to export their products in traditional markets, such as Russia, Ukraine, Turkey, Azerbaijan and Armenia. If producers will pay these costs, their costs will increase and so will the price of the product. This will make Georgian products less competitive, because price is one of the factors determining competitiveness of the product [13].

Georgia also has a free trade agreement with China that successfully contributed to increased export, especially export of wine. Further expansion of export and more intensive trade can be achieved by the "Belt and Road" initiative from Chinese government. Infrastructure projects are being implemented in the framework of the initiative, which will lead to a deepening of the relationship between Georgia and the countries involved in the route. This project can also lead to development of a unified trading system in the South Caucasus which will improve competitiveness of the region and its trade [14]. 


\section{Conclusions}

Georgian agri-food products have a potential to become more competitive on international markets with development of a sustainable transport system. Signing free trade agreements with the European Union and countries like China, show that Georgia's target export markets have a big population and variety of consumer preferences, this means that Georgian government targets expansion of export, including export of agri-food products. As Georgian agri-food export consists of primary products, they must be transported in a short period of time, which is impossible without sustainable transport infrastructure, considering the fact that main means of transport for Georgian food export are sea and road transport.

Development of a sustainable transport system links environmental protection, economic efficiency and social aspects such as standard of living and quality of life.

Infrastructure is being developed in the country, investments are made in this direction, however sustainable transport infrastructure can be created with a holistic view and a tangible strategy, considering the country's export potential and target markets. To develop transport infrastructure Investment should be made in the sector. Investments in sustainable transport system are necessary because they lead to [15]:

Geographical specialization that leads to increased productivity and comparative advantage of the country's products

- Transportation of goods over longer distances, which facilitates production in economies of scale

- Increased competition and increased variety of products for consumers

- $\quad$ Increased value of land

Development of a sustainable transport system requires lots of investments, however in the long-run it enables exported goods to become more competitive on international markets. Competitiveness of agri-food products is not defined only by transport and logistics, but without development of this system it is difficult to achieve sustainability of the export, especially of agricultural products.

\section{References}

1. Mačiulis, A., Vasiliauskas, A.Vasilis, \& Jakubauskas, G. (2010). The impact of transport on the competitiveness of national economy. Taylor \& Francis online, Transport, 24(2), 93-99. https://www.tandfonline.com/doi/pdf/10.3846/16484142.2009.24.93-99

2. Siudek, T., \& Zawojska., A. (2014). Competitiveness in the economic concepts, theories and empirical research. Oeconomia, 13(1), 91-108.

3. Rodrigue,J.P. (2006). The geography of transport systems. Transportation, Sustainability and Decarbonization. https://transportgeography.org/contents/chapter4/transportation-sustainabilitydecarbonization/

4. Kiel, J., Smith, R., \& Ubbels, B. (2013). The impact of transport investments on competitiveness. $41 \mathrm{st} \quad$ European Transport Conference. https://core.ac.uk/download/pdf/81134137.pdf

5. Lui, S. (2017). Transport and agricultural productivity: a cross-national analysis. $\begin{array}{lllll}\text { Research on Migher } & 01012 .\end{array}$ https://www.researchgate.net/publication/314219295 Transport_and agricultural_prod uctivity_A_cross-national_analysis 
6. Irigoyen, J.L. (2014). To feed the future, let's make logistics and transport sustainable. World bank blogs. https://blogs.worldbank.org/transport/feed-future-let-s-makelogistics-and-transport-sustainable

7. Strategy for agricultural development in Georgia 2015-2020. (2021). The ministry of environmental protection and agriculture of Georgia. https://mepa.gov.ge/En/PublicInformation/30/

8. PMC research center. (2018). Peach, Tangerine, raspberry value chain analysis.

9. Asian Development Bank. (2014). Georgia Transport Sector Assessment, Strategy, and Road Map. $\quad$ https:/www.adb.org/sites/default/files/institutionaldocument/34108/files/georgia-transport-assessment-strategy-road-map.pdf

10. Georgian Farmers' Association. (2020). COVID-19 impact on Georgian farmers and agriculture. $\quad$ https://gfa.org.ge/wp-content/uploads/2020/04/GFA COVID19IMPACT ENG_compressed_compressed-min reduce reduce-1.pdf

11. The world bank. (2018). Logistics performance index and its indicators. https://openknowledge.worldbank.org/bitstream/handle/10986/29971/LPI2018.pdf

12. The world economic forum. (2019). The Global Competitiveness Report 2019. http://www3.weforum.org/docs/WEF TheGlobalCompetitivenessReport2019.pdf

13. PMC research center. (2019). Analysis of agricultural sector: Value chain and export potential. https://www.research.pmcg-i.com/policypapers file/8f955d78c80e5544e.pdf

14. Zabakhidze, M., et al. (2019). Connectivity, Trade and Financial Integration of the South Caucasus Via the Belt and Road Initiative (BRI). Caucasus analytical digest, 111. https://www.research.pmcg-i.com/policypapers_file/6a7b5dd7a8a1a994b.pdf

15. Rodrigue, J.P., \& Notteboom, T. (2006). The geography of transport systems. Transport and economic development. https://transportgeography.org/contents/chapter3/transportation-and-economicdevelopment/

16. National statistics office of Georgia. (2021). https://www.geostat.ge/ka 